\title{
Distribution, habitat, and population size of Island Night Lizards on San Nicolas Island, California
}

\author{
Charles A. Drost ${ }^{1, *}$, Gary M. Fellers ${ }^{2}$, Thomas G. Murphey ${ }^{3}$, \\ Patrick M. Kleeman ${ }^{4}$, Brian J. Halstead ${ }^{5}$, and Ryan P. O’Donnell 6 \\ ${ }^{1}$ U.S. Geological Survey, Southwest Biological Science Center, Flagstaff, AZ 86001 \\ 29 Goldfinch Court, Novato, CA 94947 \\ ${ }^{3}$ Monterey Ranger District, Los Padres National Forest, King City, CA 93930 \\ ${ }^{4}$ U.S. Geological Survey, Western Ecological Research Center, Point Reyes Station, CA 94956 \\ ${ }^{5}$ U.S. Geological Survey, Western Ecological Research Center, Dixon, CA 95620 \\ ${ }_{6}^{6}$ Arizona Game and Fish Department, 5000 W. Carefree Highway, Phoenix, AZ 85086
}

\begin{abstract}
The Island Night Lizard (Xantusia riversiana) was removed from the federal list of threatened species in May 2014. This strongly differentiated species is endemic to 3 of the southern California Channel Islands-San Clemente, San Nicolas, and Santa Barbara. Suitable habitat for Island Night Lizards is extensive on San Clemente Island, and the species is abundant there. Habitat is limited and fragmented, however, on San Nicolas Island and small Santa Barbara Island. Bringing together extensive field surveys and mark-recapture sampling, we synthesize available data for Island Night Lizards on San Nicolas Island and calculate population and density estimates for the species in major habitats on the island. Island Night Lizards are widely distributed across most of the eastern half of San Nicolas Island. In contrast, they are nearly absent over the western third of the island except for isolated populations in boulder beach habitats. We combined mark-recapture population estimates with comprehensive measurements of the extent of cactus, boxthorn, and other habitat types on the island to arrive at a more accurate assessment of the status of Island Night Lizards on San Nicolas Island. High densities of Island Night Lizards on the island are found in small areas of cholla cactus (Cylindropuntia prolifera; mean of 4100 lizards/ha), boulder beach habitat (mean of 3400 lizards/ha), and prickly pear cactus (Opuntia spp.; mean of 1700 lizards/ha); low numbers are found in more extensive mixed-shrub habitat (mean of 250 lizards/ha). The U.S. Fish and Wildlife Service requires a post-delisting program for "monitoring the overall health of the Island Night Lizard" to assure the continued long-term viability of the species in its restricted distribution. The information on population size and habitat presented here will inform and guide conservation and management efforts by the U.S. Navy on San Nicolas Island over the coming years.
\end{abstract}

Resumen.-La lagartija Xantusia riversiana fue eliminada de la Lista Federal de Especies Amenazadas en mayo de 2014. Esta especie fuertemente diferenciada es endémica del sur de tres de las Islas del Canal de California (San Clemente, San Nicolás y Santa Bárbara). La Isla San Clemente cuenta con un hábitat extenso adecuado para Xantusia riversiana, por lo que la especie es abundante. Sin embargo, el hábitat es más limitado y fragmentado en la Isla San Nicolás y en la pequeña Isla Santa Bárbara. Reunimos extensos estudios de campo y muestreo de marca-recaptura, sintetizamos la información disponible sobre Xantusia riversiana en la Isla San Nicolás, y calculamos estimados de población y densidad de la especie en los principales hábitats de la isla. Xantusia riversiana se distribuye ampliamente en la mayor parte de la mitad oriental de la Isla San Nicolás. Por el contrario, se encuentra casi ausente en el tercio occidental de la isla, a excepción de poblaciones aisladas en hábitats rocosos. Combinamos las estimaciones poblacionales obtenidas a través del método de marca-recaptura con mediciones exhaustivas sobre la extensión de cactus, boxthorn africano y de otros tipos de hábitats en la isla, para lograr una evaluación más precisa del estado de Xantusia riversiana en la Isla San Nicolás. La mayor densidad de Xantusia riversiana en la isla se encuentra en pequeñas áreas de cactus cholla (Cylindropuntia prolifera, en promedio 4100 lagartijas por ha), hábitats rocosos (en promedio 3400 por ha) y nopales (Opuntia spp., en promedio 1700 por ha), mientras que, encontramos menor cantidad en hábitats extensos de arbustos mixtos (en promedio 250 por ha). Una vez eliminada esta especie de la lista de especies en amenaza, el Servicio de Pesca y Vida Silvestre de los EE.UU. requiere de un programa para "monitorear la salud general de Xantusia riversiana" para asegurar la continuidad a largo plazo de la viabilidad de la especie, dentro de su distribución restringida. La información expuesta en este estudio acerca del tamaño de la población y del hábitat puede ayudar a informar y a orientar los esfuerzos de conservación y de gestión de la marina de los Estados Unidos en la isla de San Nicolás en los próximos años.

*Corresponding author: charles_drost@usgs.gov

CAD (D) orcid.org/0000-0002-4792-7095 BJH (D) orcid.org/0000-0002-5535-6528 orcid.org/0000-0003-4092-0285

orcid.org/0000-0002-8710-7956
PMK orcid.org/0000-0001-6567-3239 
The Island Night Lizard (Xantusia riversiana) is a medium-sized lizard (adults 75-110 $\mathrm{mm}$ snout-vent length [SVL]) endemic to the Channel Islands off the coast of southern California. The species occurs on San Clemente, San Nicolas, and Santa Barbara Islands and also on one small islet (Sutil Island) just offshore of Santa Barbara Island (Bezy et al. 1980). The United States Navy manages both San Clemente and San Nicolas Islands, while Santa Barbara Island is part of Channel Islands National Park and is managed by the National Park Service. Island Night Lizards are the most morphologically distinctive of the endemic vertebrates on the Channel Islands (compared to their closest mainland relatives), reflecting a long period of isolation from the mainland (Bezy et al. 1980). Based on distinctive features of its morphology, the Island Night Lizard was formerly placed in the monotypic genus Klauberina (Savage 1957).

The Island Night Lizard was listed as a Threatened species under the U.S. Endangered Species Act in 1977 because of its restricted range, low population levels, and past and ongoing threats from habitat loss and nonnative species. Reduction and eventual removal of nonnative predators and herbivores has substantially improved conditions for the Island Night Lizard and its habitat on all 3 islands, and this led the U.S. Fish and Wildlife Service to determine that the species is no longer threatened (Carlsbad Fish and Wildlife Office 2014). On San Nicolas Island, the last nonnative predators of Island Night Lizards were feral cats (Felis catus), which were successfully removed from the island in 2009-2010 (Cypher et al. 2017).

Studies of Island Night Lizard populations and ecology have been conducted on Santa Barbara Island (Fellers and Drost 1991) and San Clemente Island (Mautz 1993). On Santa Barbara Island, Island Night Lizards are found primarily in areas of dense vegetative cover (thickets of California boxthorn [Lycium californicum] and prickly pear cactus [Opuntia oricola]) and areas with surface boulders. Ground-level cover in the form of surface rocks, deep soil cracks, or thick vegetation such as cactus pads is an important part of the species' habitat, and the lizards usually remain out of sight under such cover. Island Night Lizards on Santa Barbara Island are sedentary (with small home ranges averaging $<20 \mathrm{~m}^{2}$ ), strictly diurnal, and slow growing (with some individuals living for 12 years or more). Densities (all size/age classes) were estimated at up to 2500 lizards/ha in prickly pear habitat and 3200 lizards/ha in boxthorn. These habitats were quite restricted on the island, however, totaling a little more than 6 ha (Fellers and Drost 1991). On San Clemente Island, longterm studies found that rocky maritime desert scrub provided prime habitat for Island Night Lizards, with densities as high as 1460 lizards/ha (Mautz 1993). Analyses of growth rates and movements of marked Island Night Lizards on San Clemente Island found the lizards to be sedentary and slow growing, similar to lizards found on Santa Barbara Island. Studies and observations of movements and patterns of occurrence indicate that adult Island Night Lizards are territorial during the spring/summer breeding period (Fellers and Drost 1991).

Information on the ecology of Island Night Lizards on San Nicolas Island is, by comparison, limited. Previous published and unpublished studies (Fellers et al. 1998, 2009) have assessed overall distribution, compared relative abundance (based on capture rates) in different habitats, and evaluated population characteristics such as size distribution, growth rate, sex ratio, and aspects of reproduction including seasonality. There are no population estimates from long-term trapping studies like those on the other 2 Channel Islands where the lizards are found. San Nicolas Island is of particular interest because habitat for Island Night Lizards on the island is much more limited and fragmented due to severe overgrazing by sheep in the late 1800s and the first half of the 1900s (Swanson 1993, Junak 2008). The primary purpose of this study was to provide more accurate and detailed information on the distribution, population size, and habitat relationships of the Island Night Lizard on San Nicolas Island. These results will (1) aid in monitoring population trends of the species (as required by the U.S. Fish and Wildlife Service) after its removal from the Federal List of Threatened and Endangered Species (Carlsbad Fish and Wildlife Office 2014); (2) allow comparisons with analyses of population genetic diversity, connectivity, and isolation; and (3) inform habitat restoration work to benefit Island Night Lizards on the Channel Islands. 


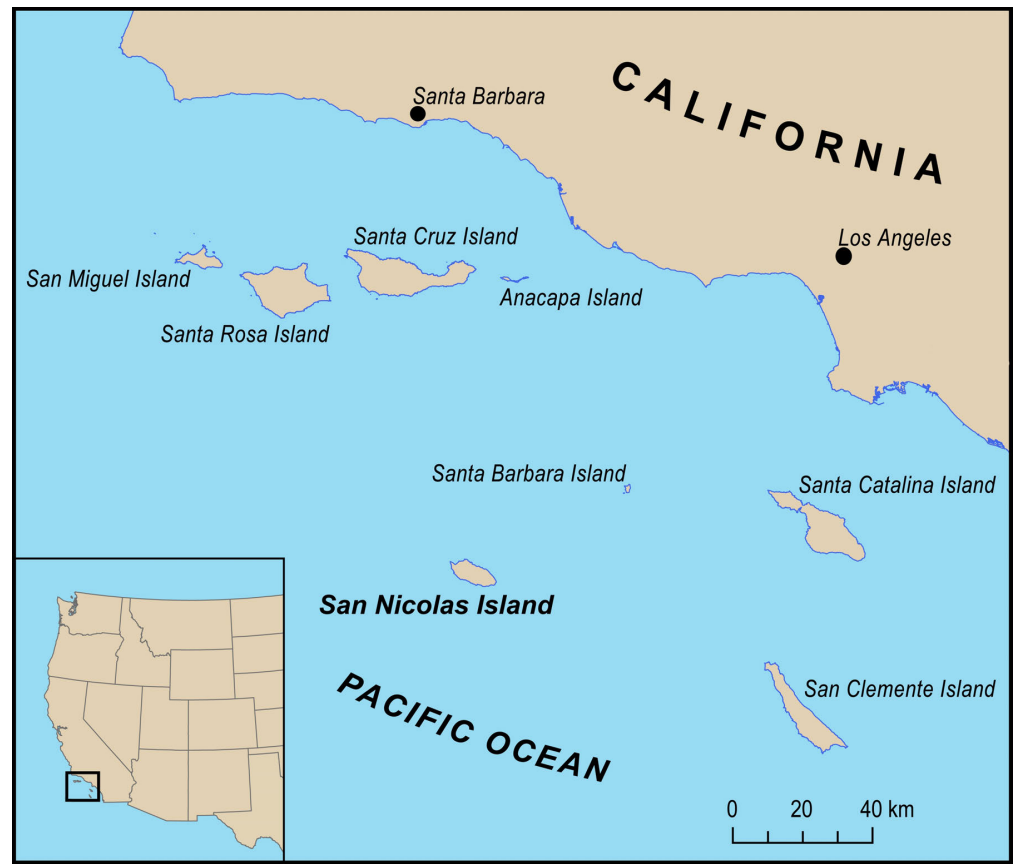

Fig. 1. Map of the southern California Channel Islands, including the location of San Nicolas Island, the site of a population study of the Island Night Lizard (Xantusia riversiana).

\section{METHODS}

\section{Study Area}

This study was conducted on San Nicolas Island, the most distant of the 8 southern California Channel Islands from the mainland coast (Fig. 1). The island is $98 \mathrm{~km}$ southsouthwest of Point Mugu, California, the nearest point on the mainland, and $155 \mathrm{~km}$ south of the city of Santa Barbara. San Nicolas is also the most isolated of the islands; the nearest islands are Santa Barbara Island, $45 \mathrm{~km}$ to the northeast, and Santa Catalina Island and San Clemente Island, both about $80 \mathrm{~km}$ distant. San Nicolas is a medium-sized island in the Channel Islands group with a land area of approximately $57 \mathrm{~km}^{2}$. The topography of San Nicolas Island is relatively simple. The island is an oblong tilted mesa oriented in an eastsoutheast to west-northwest direction, ranging from elevations of $120 \mathrm{~m}$ on the east and north to $270 \mathrm{~m}$ on the south and west. The mesa drops off in steep slopes on all sides. Because the southern edge of the mesa is tilted up, the long southern face of the island is particularly high and steep. A low terrace of 15-60 m elevation surrounds the base of the mesa and slopes gently down to the island's shoreline.
This low terrace is broadest at the west end where it tapers out to Vizcaino Point, the western tip of the island. From a biogeographic standpoint, the most significant aspect of the geology of San Nicolas Island and the surrounding Southern California Bight are the deep basins separating San Nicolas from the other islands and from the mainland coast. San Nicolas Island was completely submerged during periods of high ocean levels during the Pleistocene, and there has been no connection with other land masses since submergence (Vedder and Howell 1980). Hence, the present flora and fauna colonized the island by over-water dispersal (Savage 1957).

San Nicolas Island has a Mediterranean climate, with strong influences from the ocean. Like the surrounding islands and southern California mainland, most rainfall occurs during the winter months. Based on a 67-year record of precipitation for the island compiled during this study, mean annual precipitation is $20.0 \pm 10.7 \mathrm{~cm} /$ year $(\bar{x} \pm \mathrm{SD})$, suggesting quite arid conditions. However, because of the surrounding cold ocean, summer temperatures are relatively low and relative humidity is generally high. Mean monthly temperature ranges from $12.7^{\circ} \mathrm{C}$ in January to $16.0{ }^{\circ} \mathrm{C}$ in 
August, with mean maximum monthly temperature ranging from a low of $14.5^{\circ} \mathrm{C}$ in January to a high of $17.9{ }^{\circ} \mathrm{C}$ in October (U.S. Navy data, summarized for this study); mean relative humidity at noon is $>60 \%$ (Dunkle 1950). Frequent fog and low stratus clouds also ameliorate the low rainfall total, so the island vegetation does not have the xeric composition of desert vegetation (Dunkle 1950).

Halvorson et al. (1996) mapped vegetation communities on San Nicolas Island. Vegetation communities range from widespread goldenbush scrub (Isocoma menziesii [= Haplopappus venetus]), coreopsis scrub (dominated by giant coreopsis, Leptosyne gigantea), and grassland to more restricted bush lupine (Lupinus albifrons) scrub. Of the major communities, grassland is dominated by nonnative annual grasses (Bromus spp., Hordeum murinum, and Avena barbata), while the other communities have dominant native shrub components. Coreopsis scrub dominates the northern shore and slope of the island. The broad mesa is predominantly vegetated with goldenbush scrub and grassland, and the west slope and terrace are primarily covered with goldenbush scrub, bush lupine, and dune habitat. Most of the steep southern escarpment and shore is barren and eroded, with patches of scrub habitat.

\section{Field Methods}

We bring together information on Island Night Lizard distribution, habitat relationships, and population size on San Nicolas Island based on captures and sightings at fixed sampling sites (pitfall traps and artificial cover boards) together with general surveys of other areas across the island where traps and cover boards were not installed. Previous studies analyzed field survey data on Island Night Lizards on San Nicolas Island collected in 1984-1989 and 1992-1995 (Fellers et al. 1998) and 2001-2003 and 2005-2008 (Fellers et al. 2009). We add to the information in those studies, drawing on data collected in 2009-2016, with particular focus on population data collected during a population genetic study of the species in 2012 and 2013 (O’Donnell et al. 2018). During general surveys of the island, we noted habitat conditions, looked for prospective night lizard habitat (rock outcrops, boulders, and patches of vegetation such as prickly pear and boxthorn), and actively searched for lizards. Searches for lizards consisted primarily of turning natural cover (such as rocks, small boulders, and wood debris) and artificial cover (primarily discarded wood and metal debris); all cover objects that were moved were returned to their original positions as much as possible. We also looked for lizard sign such as droppings, shed skins, and bones in suitable areas including around surface boulders and rock outcrops. Although 2 other species of lizards are found on San Nicolas Island (Side-blotched Lizard [Uta stansburiana] and Southern Alligator Lizard [Elgaria multicarinata]; Mahoney et al. 2003), shed skins of Island Night Lizards are readily recognizable due to the species' unique scalation, and fecal pellets are usually distinguishable by size, shape, and content (because of the partially herbivorous diet of the species; Fellers and Drost 1991).

We related Island Night Lizard distribution and numbers to a new land cover GIS layer based on vegetation mapping conducted in 2013 (HDR 2014). The vegetation mapping delineated 17 vegetation associations at a minimum mapping unit of 0.10 ha using true color and infrared imagery and National Vegetation Classification Standard (NVCS) standards. Cactus and boxthorn stands (prime Island Night Lizard habitat, based on previous studies) were plotted and measured separately during exhaustive field surveys conducted by botanists from the Santa Barbara Botanic Garden (Junak 2003). These surveys recorded the location, extent, and size of cactus and boxthorn stands. We supplemented these surveys beginning in 2012 with examinations of aerial imagery of the island and follow-up field surveys to confirm and remeasure selected cactus and boxthorn sites. Several mapped plant communities that consist of variable assemblages of shrubs and herbaceous plants were judged to be equivalent in terms of their suitability for Island Night Lizards (based on whether the stature and growth form of the plants provided groundlevel cover for the lizards), so we lumped these together as "mixed-shrub" vegetation.

The overall approach to surveying and assessing distribution and abundance of Island Night Lizards on San Nicolas Island-beginning with previous studies (Fellers et al. 1998, 2009) and continuing through this study-has been to broadly cover the island, both geographically and in terms of habitat types and habitat features known or suspected to be 


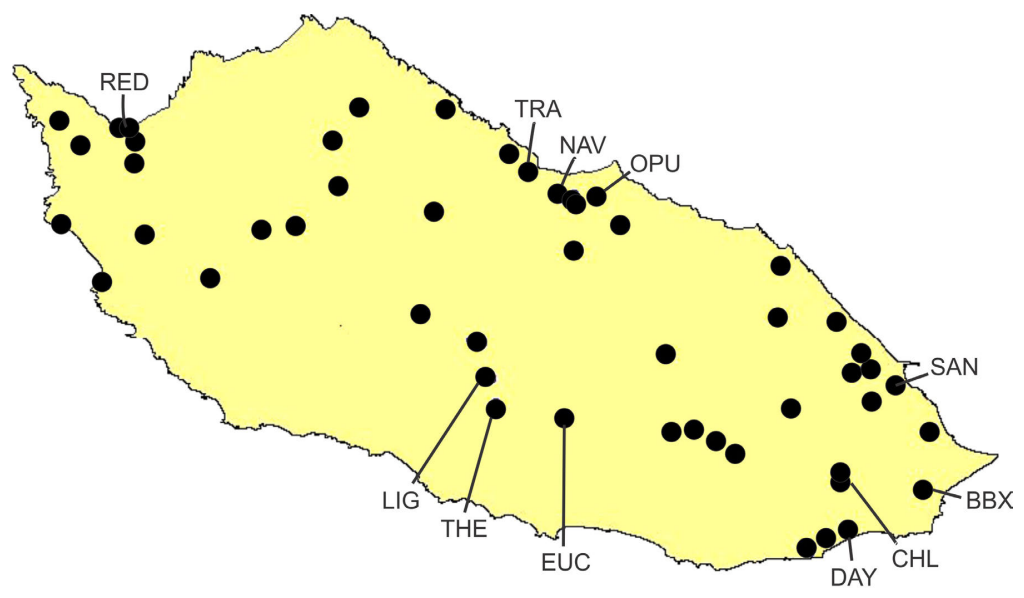

Fig. 2. Distribution of pitfall and cover board sites for sampling Island Night Lizards on San Nicolas Island. Traps and boards at each point shown were variously arrayed in transects or grids of 20-25 sampling units with typical spacing of $3 \mathrm{~m}$. Labeled points are sites used for mark-recapture population estimates: Beach Boxthorn (BBX), Cholla (CHL, 2 sites), Daytona (DAY), Eucalyptus (EUC), Lighthouse (LIG), NAVFAC (NAV), Opuntia (OPU, 2 sites), Red-eye (RED, 2 sites), Sandspit (SAN), Theodolite (THE), and Tranquility (TRA).

important to the species (Fellers and Drost 1991, Mautz 1993). Sampling sites have been added over time since preliminary studies were initiated in 1984 by the Navy Environmental Division. The overall distribution of all fixed sampling sites (pitfall traps and cover board arrays) is shown in Fig. 2. Some areas of the island-particularly the south side and the northwest corner-were closed to access and had neither pitfall traps nor cover board sites. The new data reported here are from surveys and sampling conducted since the previous studies, primarily in association with a population genetics study of the Island Night Lizard in 2012 and 2013 (O’Donnell et al. 2018). Sites for the mark-recapture analysis reported here were selected from existing sites based on coverage of major habitats, sufficiently large areas of uniform habitat, and an adequate number of captures for mark-recapture analysis. We also specifically selected some sites to correspond to the sites that were sampled for the population genetic analysis.

Lizards were captured using either pitfall traps or artificial cover boards. Pitfall traps consisted of 3.8-L (1-gallon) plastic jars sunk level with the ground and covered with a 30 $\times 30-\mathrm{cm}$ square of plywood. Traps were made operational by removing the metal lid of the jar, while leaving the plywood in place as a source of cover for lizards. Traps were installed in different configurations and usually numbered 20-25 traps per site. In dense or impenetrable habitats such as cactus patches, traps were installed in irregular lines along the edges of the habitat. Traps were also arranged in $5 \times 5$ grids of 25 traps, with spacing of $3 \mathrm{~m}$ between traps. The spacing between traps was based on average home range size obtained from previous studies (Fellers and Drost 1991). Pitfall traps were typically opened for 3 days per trapping session and checked daily when they were open.

Cover boards consisted of $29 \times 57 \times 5-\mathrm{cm}$ $(11.5 \times 22.25$-inch) pieces of Douglas-fir set in linear transects of 20 boards with a spacing of $5 \mathrm{~m}$ between boards for a total transect length of $95 \mathrm{~m}$. When a cover board was turned, we attempted to capture any lizards under the board. We generally checked boards early in the morning because the lizards were easier to catch when they were cold. Cover boards were usually checked no more than once per month to minimize disturbance of lizards in the area. Lizards were also sampled at several sites where scrap wood had been left from construction projects on the island. Two of these locations, Eucalyptus and Lighthouse, were among our main long-term sampling sites and consisted of scattered, large plywood boards $(0.6-1.2 \mathrm{~cm}$ thick, irregular lengths and widths up to $2.4 \times$ $1.2 \mathrm{~m}$ ) with interspersed low shrubs.

All captured lizards were weighed, measured, and examined to determine their sex 
and general condition. Lizards were weighed with spring scales ranging from $\pm 0.1 \mathrm{~g}$ to \pm 0.25 g precision. Snout-vent length (SVL), tail length, and length of any regenerating portion of the tail were measured to the nearest $0.5 \mathrm{~mm}$. Captured lizards were given unique numeric codes by clipping a minimum of 2 toes, but never more than one toe on each foot; this allowed us to identify recaptures both for analyses of growth and survival and also for use in mark-recapture population estimates.

Capture data used for mark-recapture population estimates included at least 3 sampling events per session (ranging up to 12) over the spring/summer season. We used the software program CAPTURE (White et al. 1982) to estimate population size and density. The population estimators calculated by CAPTURE are closed population estimators (Otis et al. 1978). Over the sampling period for our population estimate (typically 3 months or less during late spring and summer), we assumed that the local population was closed, both geographically and demographically. Geographic closure of the local site follows from the highly sedentary behavior of the lizards coupled with the suitable habitat generally being clearly demarcated and surrounded by a large area of unsuitable habitat (Fellers and Drost 1991). Demographic population closure refers to no recruitment from birth and immigration nor loss from mortality and emigration during the sampling period. Surrounding unsuitable habitat largely limits immigration into and emigration out of the local population. We did not include new young of the year $(<40 \mathrm{~mm} \mathrm{SVL})$ in our data for population size estimates. Over the short period of sampling, unknown loss from mortality in this very long-lived species was assumed to be low. CAPTURE tests markrecapture data for violation of the closure assumption and analyzes the data for sources of variation in capture probability, including differences among individuals (referred to as heterogeneity), behavioral responses to initial capture, and variation over time. Based on these tests, the program then evaluates which of a series of models best fits the form of the data. We reviewed the population estimates for all of the models for each trapping session, but we used the estimate from the model that best fit the data set (the "recommended" model from the output of the analysis).
Density estimates consist of 2 components: an estimate of the numbers of the target species in the area that was sampled and an estimate of the size of the area that was effectively sampled. Dividing the estimated population size by the size of the area sampled provides an estimate of density (in numbers per hectare or another unit of area). On San Nicolas Island the cactus and boxthorn patches generally have clearly defined edges which mark the limits of the area used by Island Night Lizards. For these habitats we used field measurements of the area of the patch as the effective area sampled for the purpose of calculating density. In more extensive and heterogeneous habitats, we used the mean maximum distance moved (MMDM) by lizards that were captured more than once (Otis et al. 1978) to define a buffer strip around the areas of the traps and cover boards. The effective area sampled was then taken as the area encompassing the traps plus the surrounding buffer strip.

One site that we report on (Sandspit) represents a total census of an area of mixedshrub habitat. This area was to be disturbed for a construction project, so Navy Environmental Division staff systematically cleared the vegetation over a $200-\mathrm{m}^{2}$ area (measured on the ground) and captured all of the lizards they found for relocation to adjacent undisturbed habitat. Vegetation was cleared from the outside to the inside and there were no boulders nor underground retreats in the area that was cleared, so all lizards at the site were accounted for. Because the survey counted all of the lizards in the cleared area at a single point in time (as opposed to sampling over an extended period with the possibility of lizards moving into and out of the edges of the area), it was not necessary nor appropriate to add a buffer strip to estimate population density.

We compared mark-recapture population estimates of lizard numbers with estimates of genetic effective population size $\left(N_{e}\right)$ that were calculated for the accompanying population genetic study of Island Night Lizards on San Nicolas Island (O'Donnell et al. 2018). Effective population size was calculated using the linkage disequilibrium method (Waples and Do 2010), as described in O'Donnell et al. (2018). For 3 of the 5 sites compared (Beach Boxthorn, Theodolite, and Cholla), the area of the mark-recapture population estimate was smaller than the area for the corresponding 


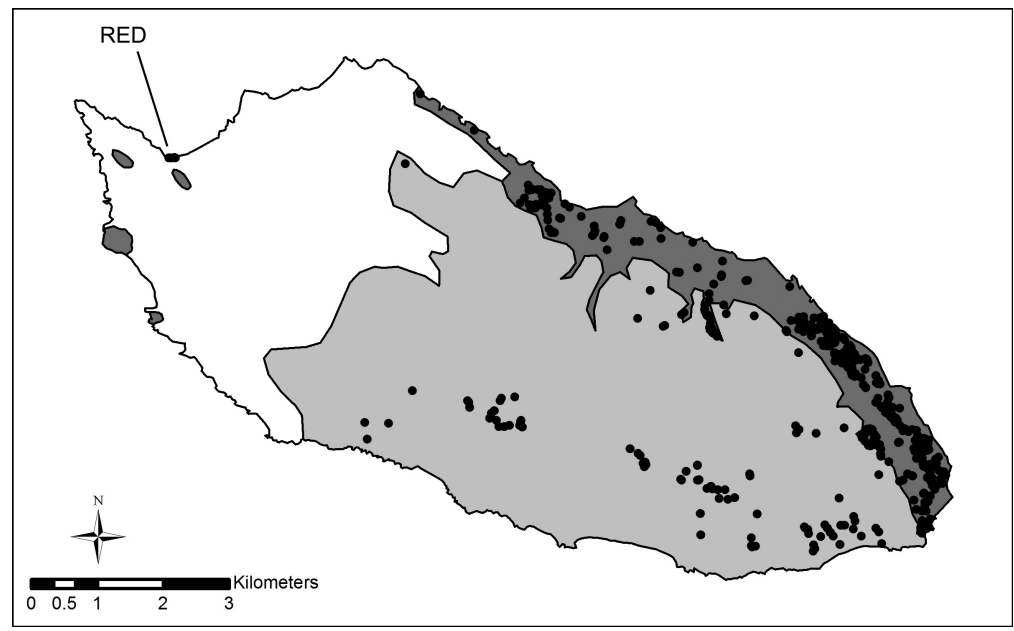

Fig. 3. Island Night Lizard (Xantusia riversiana) distribution model for San Nicolas Island. Black circles represent primary habitat, though circle size does not reflect individual patch size. Dark gray shading along the north shore of the island shows area with moderate numbers of lizards. Very few and scattered lizards occur in the area of light gray shading (primarily grassland, mixed-shrub savanna, and barren areas), and no lizards are known in the white area covering most of the west end of the island.

$N_{e}$ estimate. For these areas, we multiplied the population size estimate by the ratio of the $N_{e}$ area to the mark-recapture area so that the respective population estimates were scaled to the same area in each case.

\section{RESULTS}

\section{Distribution and Habitat}

Combined surveys from pitfall and cover board sites and general surveys across the island showed that Island Night Lizards were widely distributed in a variety of habitats over the eastern half of the island but were not found at all over nearly the entire western one-third to one-half of the island. Fig. 3 shows the estimated distribution of Island Night Lizards on San Nicolas Island. The distribution of individual cactus and boxthorn stands as well as boulder beach are shown as points on the map; these habitats support the densest populations of Island Night Lizards. Dense mixed-shrub habitat in large canyons and along the north-central and northeast margin of the island supports moderate numbers of lizards. Mixed-shrub, shrub-savanna, and grassland habitats on the central mesa of the island support low numbers of lizards.

Of the primary habitat types, prickly pear cactus totals approximately 2.7 ha on the island, boxthorn covers about 1.5 ha, cholla cactus (Cylindropuntia prolifera) totals 0.4 ha (from the survey of Junak 2003), and boulder beach totals about 0.19 ha (from our field measurements). Together these primary habitats for Island Night Lizards cover $<0.1 \%$ of the island. Cactus and boxthorn patches vary widely in size from less than $1 / 2 \mathrm{~m}^{2}$ to nearly $4200 \mathrm{~m}^{2}$ for the largest cactus patch (the filled circles in Fig. 3 are not scaled to patch size because most patches would not be visible at this scale). Lower-quality mixed-shrub habitat is much more extensive, covering over 650 ha. Cactus and boxthorn habitat is concentrated along the east and north sides of the island, with scattered areas along the south side (Fig. 3).

\section{Population Size and Density}

We calculated population and density estimates for 14 sampling sites across the island representing 5 major habitat classes on San Nicolas Island (Table 1). The total number of individual lizards captured per sampling session $\left(\mathbf{M}_{t+1}\right.$ in the terminology of Otis et al. 1978) ranged from 8 to 82 . Mean capture probability across sites was 0.25 , with most values between 0.10 and 0.31 . Converted to density, population estimates averaged 259 lizards/ha in 3 areas of mixed-shrub habitat, 1704 lizards/ha in 3 areas of prickly pear cactus, 3380 lizards/ ha in 2 sites of boulder beach habitat, and 4146 lizards in 2 cholla cactus sites (Tables 1,2). 
TABLE 1. Population and density estimates for 14 sampling sites for Island Night Lizards (Xantusia riversiana) on San Nicolas Island, California. Sampling sites are grouped by major habitat type (boulder beach, cholla, etc.). "Method" is the sampling method at each site; "area" is the estimated size of the area sampled $\left(\mathrm{m}^{2}\right)$; "population size" is the calculated number of lizards for the site, with standard error; and "density" is the calculated density (lizards/ha), with standard error.

\begin{tabular}{llccc}
\hline Site name & Method & Area & Population size & Density \\
\hline Prickly pear & & & & $1842 \pm 260$ \\
$\quad$ NAVFAC PP & Pitfall & 304 & $31 \pm 1.2$ & $1211 \pm 47$ \\
$\quad$ Opuntia Grid & Pitfall & 256 & $28 \pm 15.6$ & $2059 \pm 1147$ \\
$\quad$ Theodolite & Board & 136 & $54 \pm 14.7$ & $4355 \pm 1185$ \\
Cholla & Pitfall & 124 & $63 \pm 22.6$ & $3938 \pm 1412$ \\
$\quad$ Cholla Transect & Board & 160 & $160 \pm 34.3$ & $3292 \pm 706$ \\
$\quad$ Southeast Cholla & Boulder & 486 & $43 \pm 8.0$ & $3468 \pm 645$ \\
Boulder beach & Pitfall & 124 & $11 \pm 2.8$ & $293 \pm 75$ \\
$\quad$ Red-eye Beach & & & $7 \pm 0.6$ & $273 \pm 23$ \\
$\quad$ Red-eye Transect & Board & 376 & $6 \pm 0.2$ & $234 \pm 7.8$ \\
Boxthorn & Pitfall & 256 & $6 \pm 0.8$ & $152 \pm 20$ \\
$\quad$ Beach Boxthorn & & 256 & 7 & 350 \\
$\quad$ NAVFAC Grid & Pitfall & 396 & $11 \pm 0.5$ & $3056 \pm 139$ \\
Mixed-shrub & Board & 200 & $13 \pm 0.4$ & $4333 \pm 133$ \\
$\quad$ Daytona BBQ & Census & 36 & & \\
$\quad$ Tranquility & Board & 30 & & \\
$\quad$ Sandspit & Board & & & \\
Man-made & Eucalyptus & & & \\
$\quad$ Lighthouse & & & & \\
\hline
\end{tabular}

TABLE 2. Estimate of Island Night Lizard (Xantusia riversiana) population size in primary habitats on San Nicolas Island, California, based on measurement of area of habitat types, and estimates of lizard densities (excluding first-year individuals) in those habitats. Prickly pear cactus, cholla, California boxthorn, and boulder beach are the habitat types on the island that support the highest densities of island night lizards.

\begin{tabular}{lrcc}
\hline Habitat & $\begin{array}{c}\text { Area } \\
\left(\mathrm{m}^{2}\right)\end{array}$ & $\begin{array}{c}\text { Density } \\
\text { (lizards/ha) }\end{array}$ & $\begin{array}{c}\text { Population } \\
\text { size }\end{array}$ \\
\hline Prickly pear & 26,950 & 1704 & 4592 \\
Cholla & 4000 & 4146 & 1658 \\
Boxthorn & 14,600 & 293 & 427 \\
Boulder beach & 1900 & 3380 & 642 \\
ToTAL & & & 7319 \\
\hline
\end{tabular}

Seven Island Night Lizards were found in the $200-\mathrm{m}^{2}$ area that was completely cleared of vegetation at the Sandspit site. This was a total census of the site, with a calculated density of 350 lizards/ha. Because this was a complete census (not an estimate) and because only this site was surveyed in this manner, there is no associated measure of variability.

Multiplying the density estimates by the field-measured areas of cactus, boxthorn, and boulder beach yielded approximate numbers of lizards in the primary habitats. These numbers range from 427 in boxthorn habitat to approximately 4600 in prickly pear cactus (Table 2; first-year lizards were not included in the estimates). Mixed-shrub and shrub-savanna habitats are variable in terms of their suitability for Island Night Lizards, so we did not estimate total numbers for these habitats.

We calculated both a mark-recapture population estimate and an estimate of $N_{e}$ at 5 sampling sites (Fig. 4). Genetic effective population sizes $\left(N_{e}\right)$ were higher than the markrecapture estimates at the Beach Boxthorn and Lighthouse sites, while the mark-recapture estimates were substantially higher at the Redeye and Cholla sites. At the Theodolite site the 2 estimates were nearly identical.

\section{Discussion}

From our broad multiyear surveys across San Nicolas Island, we found that Island Night Lizards occurred across the eastern half of the island but were absent from most of the western third, evidently due to the sand substrate covering most of this portion of the island. The extensive sand dunes and sand sheets covering the western part of the island are the result of severe overgrazing dating to the 1870s (Swanson 1993, Junak 2008). The relationship between sand substrate and the absence of Island Night Lizards has been noted in earlier studies (Fellers et al. 1998). Besides the boulder beach areas, the only sites on the western third of the island where we found Island Night Lizards were 2 small strips 


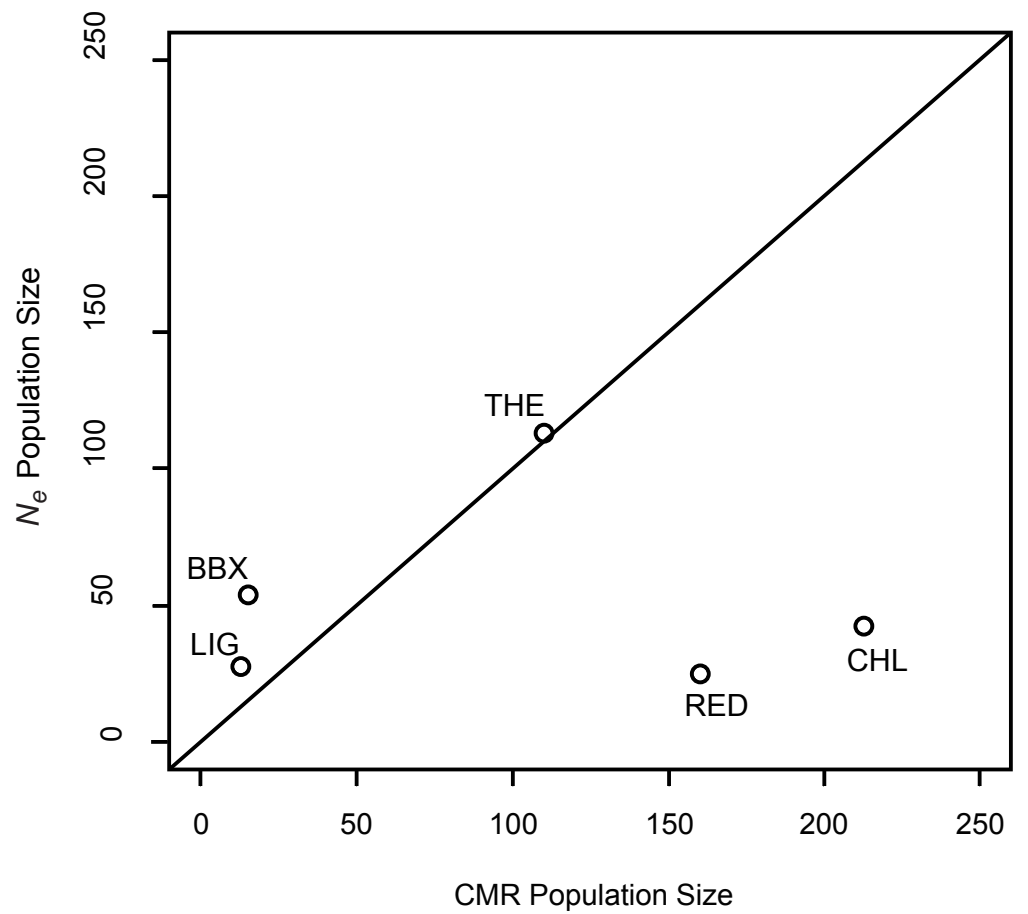

Fig. 4. Estimated genetic effective population sizes $\left(N_{e}\right.$ Population Size, $y$-axis) versus capture-mark-recapture population estimates (CMR Population Size, $x$-axis) for Island Night Lizards (Xantusia riversiana) at 5 sampling sites on San Nicolas Island. Individual sampling sites are Beach Boxthorn (BBX), Cholla (CHL), Lighthouse (LIG), Red-eye (RED), and Theodolite (THE). Data for genetic effective population size are from O’Donnell et al. (2018).

of land where the sand had been blown away by wind erosion, exposing underlying clayloam soil (small gray patches near the western tip of the island in Fig. 3).

As on Santa Barbara Island and San Clemente Island, stands of prickly pear (Opuntia littoralis and $O$. oricola) and cholla cactus support some of the densest lizard populations on San Nicolas Island. In addition, Island Night Lizards on San Nicolas were found in high numbers in boulder beach habitat in one area at the west end of the island (RED in Fig. 3). This stretch of wave-rounded boulders, driftwood, other beach debris, and bordering beach/dune vegetation was one of the only areas where we found Island Night Lizards on the western part of the island and the only site where they occurred in high numbers. In contrast to results reported from San Clemente and Santa Barbara Islands (Fellers and Drost 1991, Mautz 1993), California boxthorn thickets supported much lower numbers of Island Night Lizards on San Nicolas Island.

There was notable variation in the performance of the population model estimators among the different sampling methods and habitat types. Capture probabilities for artificial cover boards in cactus habitat (prickly pear and cholla) were low (mean 0.095, range $0.089-0.10)$. In other habitats, capture probability for cover boards was higher, ranging from 0.25 to 0.31 . This probably reflects the relative attractiveness of these artificial cover sites as retreats in the different habitats (e.g., cactus patches offer abundant ground-level cover while mixed-shrub sites offer very little). This difference strongly indicates caution against uncritical comparison of relative capture rates for cover board surveys in different habitats. In the cactus habitats, pitfall capture probabilities were generally high $(0.25-0.30)$ but estimated recapture probabilities were quite low (0.0095-0.020), suggesting that Island Night Lizards in cactus habitats tend to avoid trap sites after a first capture. In other habitats, capture probabilities did not differ significantly between first capture and subsequent captures.

The count for the Sandspit mixed-shrub habitat is a total census for that $200-\mathrm{m}^{2}$ area. 
It is usually difficult or impossible to obtain a complete census of a habitat area for secretive species-in particular, systematic destruction of the habitat as described here would rarely be allowed. Although we have only one site in one habitat for this total census, the data from this site provides a valuable comparison and check of the estimated population numbers for similar areas of mixed-shrub habitat.

As noted, the Eucalyptus and Lighthouse sites are essentially man-made habitats. Large pieces of plywood and other wood debris provide the majority of cover and effective habitat at these sites, with adjacent goldenbush shrubs providing some additional habitat. Because boards are the main cover used by Island Night Lizards at these sites, over half of the lizards present are typically captured during an individual sampling session (estimated capture probabilities of $0.54-0.55$ ), so our counts and calculated estimates of population numbers approach total censuses over just 2 or 3 sampling visits. In addition, measurements of total habitat area for these sites are precise and accurate because the habitat area used by the lizards is limited to the cover boards themselves and immediately adjacent shrubs. The sites are otherwise surrounded by low annual grassland and bare ground that is very poor habitat for Island Night Lizards.

Close correspondence of the population estimates for different sites within the same habitat (Table 1) provides a measure of confidence in the estimates for that habitat type. This is particularly true in cases where different sampling methods were used. At Red-eye (RED in Fig. 2), for example, we calculated mark-recapture estimates from a transect of pitfall traps-a passive, though typically effective, capture method-and we also calculated mark-recapture estimates from a series of active searches (by turning boulder cover) of a relatively large area of the boulder beach $(50 \times 5 \mathrm{~m})$. The density estimate from the pitfall transect was 3468 lizards/ha, and the estimate from the active searches in a defined area of boulder beach was 3292 lizards/ha. For the most structurally and compositionally variable habitat, the mixed-shrub association, we calculated estimates from pitfall trap grids, cover boards, and the total census of the cleared area at the Sandspit site. The mixedshrub estimates ranged from 152 lizards/ha at the Tranquility site to 350 lizards/ha at the
Sandspit total census site. This range represents a reasonable amount of variation given the variability of the mixed-shrub association in terms of plant species composition, vegetation density, and ground-level cover (including boulders, burrows, and earth cracks in some places). The Tranquility site is composed of mixed-shrub habitat near the western edge of the main distribution of Island Night Lizards on San Nicolas Island where the substrate grades into sandy soil, which may contribute to lower numbers at this site.

Population estimates for cactus habitats on San Nicolas Island compare favorably with those reported on Santa Barbara and San Clemente Islands. For prickly pear stands, estimated densities on San Nicolas Island range from 1211 to 2059 subadult and adult lizards per hectare. Estimates for cholla cactus habitat range up to 4000 lizards/ha or more (Table 1), but these estimates have wide confidence bounds. In mixed boxthorn-cactus habitat on San Clemente Island, mark-recapture estimates ranged from 1337 to 1633 Island Night Lizards per hectare (Mautz 1993). On Santa Barbara Island, Island Night Lizard densities (all size/age classes, including juveniles) based on intensive trapping in pure prickly pear cactus were estimated at 2476 lizards/ha (Fellers and Drost 1991).

Estimated densities in pure boxthorn stands on Santa Barbara Island were the highest recorded on that island at over 3200 lizards/ha (all size/age classes). In contrast, density estimates for boxthorn habitat on San Nicolas Island (mean of 293 lizards/ha) are less than one-tenth the number reported for Santa Barbara Island. Boxthorn in the Beach Boxthorn sampling site on San Nicolas Island is patchy, low in stature, and located on a hard, open substrate. Both in the overall character of the habitat and in estimated densities, this area is more similar to the mixed-shrub type on the island. The scarcity of deep earth cracks and other surface cover in these boxthorn patches on San Nicolas Island may account for the comparatively low numbers of lizards. Surface cover for thermal buffering and protection from predators is evidently essential for good Island Night Lizard habitat (Fellers and Drost 1991, Mautz 1993), and this sort of cover was generally lacking in boxthorn sites examined on San Nicolas Island. 
Mark-recapture estimates of population size differed widely from estimates of genetic effective population size $\left(N_{e}\right)$ for selected sites on San Nicolas Island (Fig. 4; cf. O’Donnell et al. 2018). Mark-recapture estimates were lower than $N_{e}$ for 2 sites on the island and much higher than $N_{e}$ at 2 other sites (Fig. 4). $N_{e}$ is typically interpreted as the number of individuals contributing to the next generation, so it is generally lower than census population size-sometimes markedly so (Palstra and Fraser 2012). The highly isolated Red-eye site stands out for its very low $N_{e}$ estimate compared to the large population of adult lizards known at this site (both the population estimate and the total number of lizards captured at the site-which is an empirical lower bound on the estimate-were considerably higher than $N_{e}$ ). In contrast, the number of adult lizards at the Lighthouse site is known quite accurately because the cover for Island Night Lizards at this site can be thoroughly searched; the $N_{e}$ estimate at this site was about twice the mark-recapture estimate (27.2 vs. 13 ; O’Donnell et al. 2018).

The Lighthouse site appears to be isolated from other local populations; the site is 200-250 m from the next nearest patch of suitable habitat. However, we suspect that it and other sites with a comparable level of isolation still receive low levels of immigration from surrounding local populations. In other words, the population is not effectively closed genetically, so the estimate of $N_{e}$ corresponds to a larger area than the extent represented by the mark-recapture estimates. By comparison, the Southeast Cholla and Red-eye sites, which have relatively low estimates of $N_{e}$, are much more isolated. Southeast Cholla is over $1 \mathrm{~km}$ from the nearest large source population, and Red-eye is the most isolated large population of Island Night Lizards on San Nicolas Island, $3.5 \mathrm{~km}$ from the next closest source population. These sites are evidently nearly or completely cut off to genetic exchange, and we hypothesize that the low estimates of $N_{e}$ reflect that isolation. The Island Night Lizards at the Red-eye site, in particular, appear to represent a relictual population from the time before severe vegetation stripping by introduced sheep resulted in the highly fragmented distribution of suitable night lizard habitat on San Nicolas Island (Junak 2008, O’Donnell et al. 2018).
Further research is needed to follow up on the patterns and function of dispersal in this sedentary species. Previous studies have highlighted the small home ranges and limited movements of Island Night Lizards and their congeners, with individuals recorded consistently at the same small site for 6 years or more (Island Night Lizards recorded at the same rock shelter for up to 6 years, Mautz 1993; Desert Night Lizards, Xantusia vigilis, recorded under the same fallen Joshua Tree branch for similar periods, Zweifel and Lowe 1966). Longer movements have been documented (Fellers and Drost 1991), however, and we suspect that these movements are made primarily by young individuals. The effective distance of these movements and the time required to colonize new habitats need additional study. We suspect that such rare long-distance movements result in the maintenance of relatively high levels of local genetic diversity in spite of the much-reduced and highly fragmented habitat on San Nicolas Island (O’Donnell et al. 2018). In turn, we believe that habitat restoration efforts that create "stepping-stone" islands of habitat may function more effectively to promote genetic connectivity and diversity compared to restoration actions that enlarge existing habitat patches or create new patches in close proximity to existing patches.

Improved estimates of both Island Night Lizard density and areal extent of habitats used by Island Night Lizards on San Nicolas Island are important baseline values for monitoring trends in Island Night Lizard population size and habitat conditions. Long-term monitoring is required under the U.S. Fish and Wildlife Service rule that removed the Island Night Lizard from the Federal List of Threatened and Endangered Species (Carlsbad Fish and Wildlife Office 2014). High-quality habitat for Island Night Lizards on San Nicolas Island is currently quite limited. Demographic and genetic isolation due to small, scattered habitat patches remains a concern. The last grazing animals were removed from the island in 1949, however, and native vegetation has been gradually expanding since that time (Junak 2008). Ongoing habitat restoration on San Nicolas Island by the U.S Navy focuses in part on cacti and boxthorn, specifically to benefit Island Night Lizards. These restoration efforts combined with natural 
vegetation recovery should contribute to positive trends in distribution and numbers, population stability, and genetic connectivity for Island Night Lizards on this remote outpost.

\section{ACKNOWLEDGMENTS}

We thank the United States Navy, Naval Base Ventura County, for support and encouragement of this work. Special thanks go to Grace Smith, Bill Hoyer, and Martin Ruane, navy biologists for San Nicolas Island, for help with logistics, general assistance, observations in the field, and all-around support. We also thank Bill Mautz for his help, insights, and discussion on Island Night Lizard ecology. The U.S. Geological Survey provided partial funding for this work. Any use of trade, product, or firm names in this publication is for descriptive purposes only and does not imply endorsement by the United States government.

\section{Literature Cited}

Bezy, R.L., G.C. Gorman, G.A. Adest, and Y.J. Kim. 1980. Divergence in the Island Night Lizard Xantusia riversiana (Sauria: Xantusiidae). Pages 565-583 in D.M. Power, editor, The California Islands: Proceedings of a Multidisciplinary Symposium. Santa Barbara Museum of Natural History, Santa Barbara, CA.

Carlsbad Fish and WiLdLIFE OfFICE. 2014. Endangered and Threatened Wildlife and Plants; Removing the Island Night Lizard from the Federal List of Endangered and Threatened Wildlife. Federal Register 79, No. 62:18190-18210. April 1, 2014.

Cypher, B.L., E.C. Kelly, F.J. Ferrara, C.A. Drost, T.L. Westall, and B.R. Hudgens. 2017. Diet patterns of island foxes on San Nicolas Island relative to feral cat removal. Pacific Conservation Biology 23: $180-188$

DunKLe, M.B. 1950. Plant ecology of the Channel Islands of California. University of Southern California Allan Hancock Pacific Expeditions 13(3):247-386.

Fellers, G.M., AND C.A. Drost. 1991. Ecology of the Island Night Lizard, Xantusia riversiana, on Santa Barbara Island, California. Herpetological Monographs 5:28-78.

Fellers, G.M., C.A. Drost, W.J. Mautz, and T. MurPHEY. 1998. Ecology of the Island Night Lizard, Xantusia riversiana, on San Nicolas Island, California. U.S. Navy Report. 80 pp.

Fellers, G.M., C.A. Drost, and T. Murphey. 2009. Status of the Island Night Lizard and two non-native lizards on outlying landing field San Nicolas Island, California. U.S. Geological Survey Open-File Report 2008-1371. 22 pp.

Halvorson, W.L., S. Junak, C. Schwemm, and T. Keeney. 1996. Plant communities of San Nicolas Island, California. Technical Report No. 55, U.S. Department of Interior, Cooperative Park Resources Studies Unit, University of Arizona, Tucson, AZ.
HDR. 2014. Vegetation classification and mapping, Naval Base Ventura County, San Nicolas Island, California. Naval Facilities Engineering Command. http://nrm .dfg.ca.gov/FileHandler.ashx? DocumentID $=88543$

JunaK, S. 2003. Distribution of native cacti (Opuntia spp.) and boxthorn (Lycium californicum) on San Nicolas Island, California. Santa Barbara Botanic Garden, Technical Report No. 3. Santa Barbara, CA

JunAK, S. 2008. A flora of San Nicolas Island, California. Santa Barbara Botanic Garden, Santa Barbara, CA.

Mahoney, M.J., D.S. Parks, and G.M. Fellers. 2003. Origin of Uta stansburiana and Elgaria multicarinata on the California Channel Islands: natural dispersal versus artificial introductions. Journal of Herpetology 37:586-591.

MautZ, W.J. 1993. Ecology and energetics of the Island Night Lizard, Xantusia riversiana, on San Clemente Island, California. Pages 417-428 in F.G. Hochberg, editor, Third California Islands Symposium: recent advances in research on the California Islands. Santa Barbara Museum of Natural History, Santa Barbara, CA.

O’Donnell, R.P., C.A. Drost, G.M. Fellers, B.A. Crabb, and K.E. Mock. 2018. Rare long-distance dispersal of the Island Night Lizard, Xantusia riversiana, maintains high diversity in a fragmented environment. Conservation Genetics 19:803-814

Otis, D.L., K.P. Burnham, G.C. White, and D.R. AndersON. 1978. Statistical inference from capture data on closed animal populations. Wildlife Monographs 62: $1-135$.

Palstra, F.P., AND D.J. Fraser. 2012. Effective/census population size ratio estimation: a compendium and appraisal. Ecology and Evolution 2:2357-2365.

Savage, J.M. 1957. Studies on the lizard family Xantusiidae, III: a new genus for Xantusia riversiana (Cope, 1883). Zoologica 42:83-86.

SWANSON M.T. 1993. Historic sheep ranching on San Nicolas Island. Technical Series 41, Statistical Research, Inc., Tucson, AZ.

VedDER, J.G., AND D.G. Howell. 1980. Topographic evolution of the southern California borderland during late Cenozoic time. Pages 7-31 in D.M. Power, editor, The California Islands: proceedings of a multidisciplinary symposium. Santa Barbara Museum of Natural History, Santa Barbara, CA.

WAPLES, R.S., AND C. Do. 2010. Linkage disequilibrium estimates of contemporary $\mathrm{N}_{\mathrm{e}}$ using highly variable genetic markers: a largely untapped resource for applied conservation and evolution. Evolutionary Applications 3:244-262.

White, G.C., D.R. Anderson, K.P. Burnham, and D.L. OTIs. 1982. Capture-recapture and removal methods for sampling closed populations. Report LA-8787NERP, Los Alamos National Lab, Los Alamos, NM.

ZweIfEL, R.G., AND C.H. LowE. 1966. The ecology of a population of Xantusia vigilis, the Desert Night Lizard. American Museum Novitates 2247:1-57.

Received 2 March 2017

Revised 17 October 2017

Accepted 12 January 2018

Published online 28 September 2018 